\title{
Crop Water Productivity of Plantain (Musa Sp) in a Humid Tropical Environment
}

\author{
A. O. Akinro ${ }^{1, *}$, A. A. Olufayo ${ }^{2}$, P. G. Oguntunde ${ }^{2}$ \\ ${ }^{1}$ Department of Civil Engineering Technology, Rufus Giwa Polytechnic, P.M.B 1019, Owo, Nigeria. \\ ${ }^{2}$ Department of Agricultural Engineering, Federal University of Technology, Akure, Nigeria.
}

Received 23 March 2011; Accepted 10 February 2012

\begin{abstract}
Crop water productivity defines the relationship between crop produced and the amount of water involved in producing the crop. It is a useful indicator for quantifying the impact of irrigation scheduling decisions with regard to water management. This paper presents CWP quantified from field experimental data. The field experiments were conducted for three years in a tropical region of south Western Nigeria to determine the crop water productivity (CWP) and consumptive use of plantain (musa sp) cv. Agbagba. There were four treatments and four replicates based on the level of water application. CWP were computed in terms of crop water use, water applied, and economic returns. Results showed that crop water consumed varied significantly $(\mathrm{P}<0.05)$ among treatments. Estimated water consumed ranged from 900 $\mathrm{mm}$ to $1700 \mathrm{~mm}$ from planting to harvest depending on the irrigation water regime. Crop Water Productivity (CWP) in terms of water consumed varied from $0.91-1.37 \mathrm{kgm}^{-3}$ for $2006 / 2007$ and $0.91-1.41 \mathrm{kgm}^{-3}$ in the 2007/2008 seasons respectively while CWP in terms of water applied varied from $2.82-3.98 \mathrm{kgm}^{-3}$ and $2.89-4.04 \mathrm{kgm}^{-3}$ in the first and second seasons respectively. The amount of irrigation water applied at the different growth stages of the crop and the growth stage response to moisture stress influenced the status of CWP. The findings indicated that plantain crops were very sensitive to lack of soil water during the total growing season.
\end{abstract}

Keywords: Plantain biomass, bunch yield, evapotranspiration, crop water productivity, musa, consumptive use.

\section{Introduction}

Plantains and bananas constitute the fourth most important crop of the world after rice, wheat, and maize and they form the world's second most important traded fruit after citrus, and along with rubber (Castilla elastica), cocoa (Theobroma cacao L.), sugar (Saccharum officinarum L.) and coffee (Coffee Arabica L.) one of the five major tropical products entering into world trade [1].

The world plantain area totaled 4.8 million hectares producing 30.6 million tonnes of fruits. The regions with the largest production are Africa and Latin America with respectively $74.2 \%$ and $22.5 \%$ of world production in comparison with $3.3 \%$ in Asia [2]. Plantains flourish in tropical regions and are the most important carbohydrate source in local economies [3]. In West and Central Africa about 70 million people are estimated to depend on Musa fruits for a large proportion of their daily carbohydrate intake [4].

In Nigeria plantains and bananas are both important staples and sources of income for subsistence farmers. There has been increasing trend towards large-scale production of the crop [5] in the traditional humid rainforest production zone, and some emergent production zones are located in the sub-humid areas of southeastern Nigeria [6-7]. However most of the increases in plantain production have been due to cropland expansion, rather than increases in yield per

*E-mail address: akinroakinola@yahoo.com

ISSN: 1791-2377 @ 2012 Kavala Institute of Technology. All rights reserved. hectare. Presently, plantain cultivation has become a feature of great socioeconomic importance in developing countries from the point of view of food security and job creation [8].

Although some research has been conducted on this important crop [9-13], little documented evidence exist to indicate the manner in which the plantain plant uses water or respond to irrigation with respect to yields. Bassoi et al., [13] stated that water is probably the most limiting nonbiological factor in plantain production. It is known generally as a plant with a rapid growth rate, high consumption of water, shallow and spreading root distribution, roots with weak penetration strength into the soil [14], low resistance to drought and rapid physiological response to soil water deficit [15].

Data on water use of plantain grown in the tropical humid conditions are essential for optimum irrigation management strategies and water conservation. Crops in general, have reduced crop growth and yields due to soil moisture deficits and hence reduced leaf photosynthesis and a combination of stomatal and non-stomatal limitations [1621]. The effects of this drought depend on the phenelogical stages when it occurs [22-23]. In the case of plantain, Robinson and Bower, [24] and Eckstein et al., [25]; Eckstein and Robinson, [26] noted that photosynthetic activity decreases with reduction of transpirational and stomatal aperture. Proper irrigation management of plantain should therefore lead to improved productivity and continuous fruits harvest especially in tropical regions where rainfall amounts and distribution are erratic. 
Water is a limiting resource and hence the need for its judicious use. In many tropical regions of the world, water (not land) is the most limiting factor to plantain production. Research work on water use productivity (CWP) or water use efficiency (WUE) is a major input to good irrigation water management for sustainable agriculture in irrigated areas [27]. However, studies upon the estimates of crop water productivity for plantains are still incipient. Satisfying crop water requirements, although maximizes production from the land unit; does not necessarily maximize the return per unit volume of water. Improving water productivity can contribute to water savings, which can be used to irrigate additional lands with higher total production and/or improve the sustainability of the existing water resources. However, the supplementary irrigation level at which crop water productivity can be maximized under the rainfed conditions of the humid tropical environment need to be evaluated before improved management strategies can be devised. Thus, the objective of this study was to evaluate the evapotranspiration, yield and crop water productivity of plantain cv. Agbagba, grown under tropical climate conditions.

\section{Materials and Methods}

\subsection{Experimental site and design}

Suckers of plantain, cultivar Agbagba (musa paradisiaca sp. AAB) were planted in a field experiments between July 2006 - November 2007 and August 2007 - November 2008 at the Experimental Farm of the Department of Agricultural Engineering, Federal University of Technology, Akure, South West Nigeria which lies at latitude $7^{\circ} 16^{\prime}$ North and longitude $5^{\circ} 13^{\prime}$ East at an altitude of $351 \mathrm{~m}$ above mean sea level. Akure is located in a tropical humid climate with rains spanning up to half of the year. The mean annual rainfall between 1995 and 2007 is about $1300 \mathrm{~mm}$ while the minimum and maximum temperatures are about $20^{\circ} \mathrm{C}$ and $30^{\circ} \mathrm{C}$. Mean monthly weather conditions at the experimental location during 1995-2007 are shown in Table 1. Sample of the soil was analyzed at the beginning of the experiments as shown in Table 2. According to FAO classification the soil belongs to category of fine, loamy, mixed hyperthermic Typic Haplauf. The upper layer $(0-0.15 \mathrm{~m})$ down the other layers examined $(0.15-0.30 ; 0.30-0.45 ; 0.45-0.60 \mathrm{~m})$ were sandy clay loam in texture. The average bulk density is about $1.5 \mathrm{gcm}^{-3}$.

Each experiment was laid out in 16 plots of $20 \mathrm{~m} \mathrm{x} 40 \mathrm{~m}$ in a 4 x 4 Randomized Complete Block Design having treatments based on four different levels of water application (see Table 3). A plot was $2 \mathrm{~m} \mathrm{X} 6 \mathrm{~m}$ with planting density of 2500 plants ha ${ }^{-1}$ similar to prevailing cultural practice within the locality and in literature [28]. Weeds were controlled chemically and manually and fertilizer was applied based on soil chemical analysis.

The consumptive use of water by the crop was estimated using the water balance equation

$E T=I+P \pm \Delta S \pm R \pm D$

where ET = actual evapotranspiration in $\mathrm{mm}$; I = amount of irrigation water $(\mathrm{mm}) ; \mathrm{P}=$ effective rainfall $(\mathrm{mm}) ; \Delta \mathrm{S}=$ change in soil water storage $(\mathrm{mm}) ; \mathrm{R}=$ surface runoff, $(\mathrm{mm})$ and $\mathrm{D}=$ amount of drainage water $(\mathrm{mm})$.
Table 1. Weather conditions at the experimental location (1995-2007)

\begin{tabular}{|c|c|c|c|c|c|}
\hline Months & $\begin{array}{l}\text { Precipitation } \\
(\mathrm{mm})\end{array}$ & $\begin{array}{c}\text { Reference } \\
\text { evapotranspiration } \\
(\mathrm{mm})\end{array}$ & $\begin{array}{c}\text { Air } \\
\text { temperature } \\
\left({ }^{\circ} \mathrm{C}\right)\end{array}$ & $\begin{array}{l}\text { Relative } \\
\text { humidity } \\
\quad(\%)\end{array}$ & $\begin{array}{c}\text { Wind } \\
\text { speed: } \\
2 \mathrm{~m} \\
\text { high } \\
\left(\mathrm{ms}^{-1}\right)\end{array}$ \\
\hline January & 19.3 & 3.1 & 26.8 & 58.5 & 3.5 \\
\hline February & 44.7 & 3.6 & 29.9 & 62.3 & 4.4 \\
\hline March & 37.9 & 3.4 & 30.7 & 61.4 & 4.8 \\
\hline April & 173.2 & 3.7 & 30.3 & 73.6 & 5.4 \\
\hline May & 134.2 & 3.8 & 28.5 & 80.0 & 4.1 \\
\hline June & 199.7 & 2.8 & 27.0 & 80.9 & 3.2 \\
\hline July & 155.3 & 2.2 & 25.6 & 86.8 & 3.4 \\
\hline August & 62.6 & 4.7 & 25.2 & 86.0 & 3.8 \\
\hline September & 240.6 & 1.9 & 26.1 & 85.1 & 2.3 \\
\hline October & 172.7 & 2.6 & 27.2 & 82.6 & 6.6 \\
\hline November & 28.1 & 3.2 & 28.8 & 73.9 & 2.1 \\
\hline December & 14.7 & 3.6 & 27.1 & 71.2 & 3.3 \\
\hline Total & 1282.9 & - & - & - & - \\
\hline Mean & & 3.0 & 27.7 & 75.2 & 3.9 \\
\hline \multicolumn{6}{|c|}{$\begin{array}{l}\text { Location of the Experimental Station: latitude } 7^{\circ} 16^{\prime} \mathrm{N} \text {; longitude } 5^{\circ} 13^{\prime} \mathrm{E} \text {, } \\
\text { altitude of } 351 \mathrm{~m}\end{array}$} \\
\hline
\end{tabular}

Table 2. Measured soil physical and hydrological properties at the experimental site

\begin{tabular}{lr}
\hline Characteristic & Value \\
\hline Sand (\%) & 64.0 \\
Clay (\%) & 24.5 \\
Silt (\%) & 11.5 \\
Organic matter (\%) & 1.61 \\
Bulk density $\left(\mathrm{gcm}^{-3}\right)$ & 1.50 \\
Field capacity (\%) & 20.60 \\
Wilting Point (\%) & 3.43 \\
pH & 5.73 \\
\hline
\end{tabular}

Table 3. Summary of Irrigation Treatments

\begin{tabular}{lll}
\hline Treatment & Code & Definition \\
\hline High (full) & T1 & $0 \%$ deficit irrigation \\
Moderate & T2 & $50 \%$ deficit irrigation \\
Low & T3 & $75 \%$ deficit irrigation \\
Control & T0 & Control experiment \\
\hline
\end{tabular}

Water was applied using low gravity drip irrigation system and emitters were spaced along polyethylene lines with stopcock controls at each end of the line to control the timing and quantity of water applied. Irrigation amount was recorded at every water application. The change of soil water storage, $\Delta \mathrm{S}$ was estimated from moisture content readings up to a depth of $50 \mathrm{~cm}$ which was assumed to be the root zone. Runoff was estimated using runoff meters. For periods without rainfall, runoff was obviously nil. The drainage below root zone was estimated using Darcy's equation. A Watermark Soil Moisture Sensor and the Multipurpose Temperature Probe used with the Vantage Pro2 wireless soil moisture/Temperature station was installed on the experimental field to monitor the soil moisture and soil temperature. Soil moisture contents were also determined by gravimetric method. This was measured in each treatment plot to depths of $50 \mathrm{~cm}$ at $10 \mathrm{~cm}$ interval starting from the soil surface. Rainfall data were collected using standard rain gauges installed at various points of the experimental farm. The rain gauges were regularly raised above crop canopy to avoid errors due to rainfall interception. Reference evapotranspiration $\left(\mathrm{ET}_{\mathrm{ref}}\right)$ was 
calculated using monthly temperature, humidity, solar radiation and wind speed according to the FAO Penman Monteith Method [29].

Growth analysis was carried out monthly by harvesting plant material from randomly selected plots of each treatment. Samples were taken in all replicates. Plants were harvested and separated into dry leaves, wet leaves, pseudostem, corm, and fruits. The fresh and dry mass of each sample were determined. Dry matter of plants organs were determined by drying samples in an oven at $65^{\circ} \mathrm{C}$ for $48 \mathrm{hrs}$. Bunch yield and dry matter yield were determined at maturity. Crop water productivity was calculated as:

i. Crop water productivity in terms of seasonal crop consumptive use:

$$
\mathrm{CWP}_{(\text {water use })}=\frac{\text { crop } \text { yield }(\mathrm{kg})}{S W U\left(\mathrm{~m}^{3}\right)}
$$

ii. Crop water productivity in terms of seasonal water applied to the field:

$$
\mathrm{CWP}_{(\text {water applied })}=\frac{\text { crop yield }(\mathrm{kg})}{S W A .\left(\mathrm{m}^{3}\right)}
$$

iii. Crop water productivity expressed in economic term:

$$
\mathrm{CWP}_{(\text {economic })}=\frac{p \times \text { crop yield }}{S W A .\left(m^{3}\right)}
$$

where $p=$ price of plantain bunch (price $/ \mathrm{kg}$ crop yield).

The price of plantain bunch yield in the study area during the $2006-2008$ irrigation seasons was equivalent to $\$ 1.33 / \mathrm{kg}$ based on market survey. Analysis of data was carried out using statistical softwares such as the Statistical Package for Social Sciences (SPSS), Statgraph, MS Excel and Sigma plot 10.0.

\section{Results and discussions}

\subsection{Crop Evapotranspiration (Crop Water Use)}

Variations of mean crop evapotranspiration estimates for all treatments are shown as Figure 1. Evapotranspiration against days after planting fitted best to parabolic functions for all treatments with the coefficient of correlation $\left(\mathrm{R}^{2}\right)$ ranging from 0.65 to 0.91 [30]. The crop water use was lowest at the emergence and vegetative stages of the plants. It reached the peak at the flowering stages and finally dropped at the maturity/harvest stage. Evapotranspiration is generally higher during the dry season than during the wet season and this was so because of the high solar radiation which resulted to rapid loss of moisture both from soil and the crop surfaces in order to respond to evaporative demand. The maximum value of ET (10.7 mmday $\left.^{-1}\right)$ was observed among T1 treatment at the 279DAP. Results from the T2 treatment (Figure 2 (b)) showed that 8.1 mmday $^{-1}$ was the highest ET value. Observations among the low treatment (T3) revealed that 6.79 mmday $^{-1}$ was the highest ET while 6.35 mmday $^{-1}$ was the highest ET among the control treatment, T0.

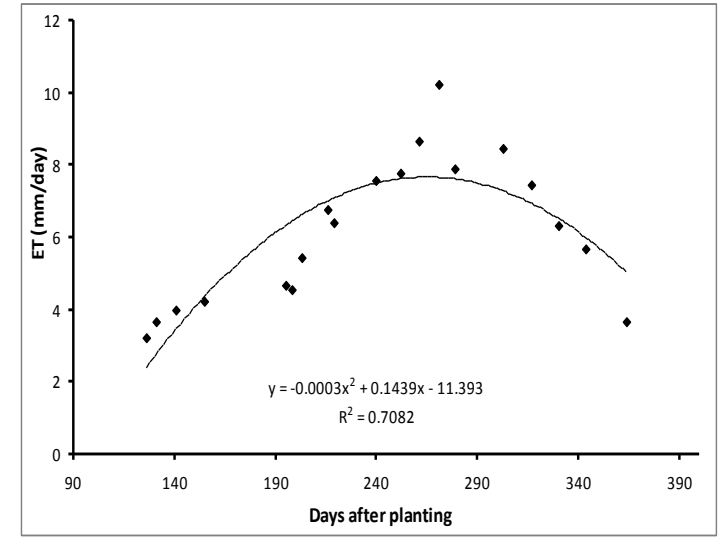

a

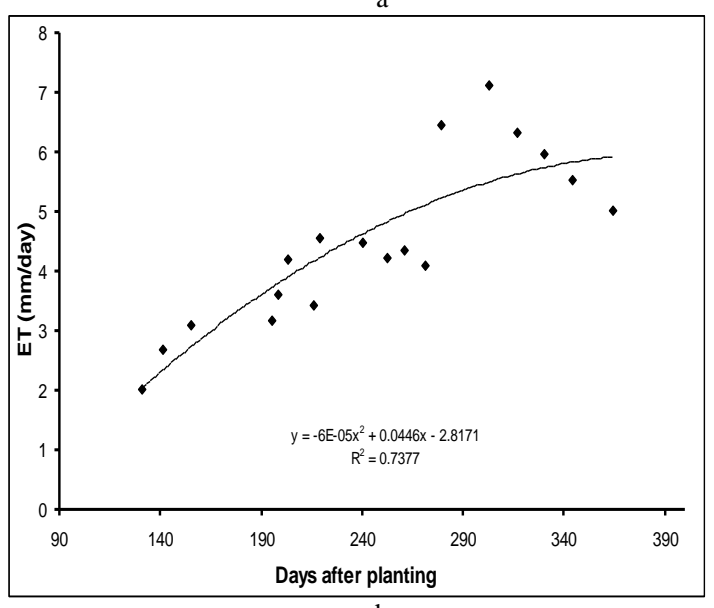

b

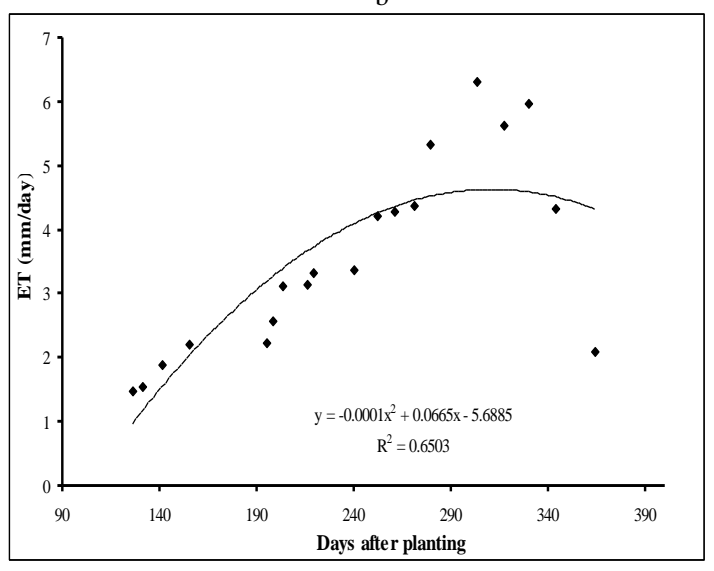

c

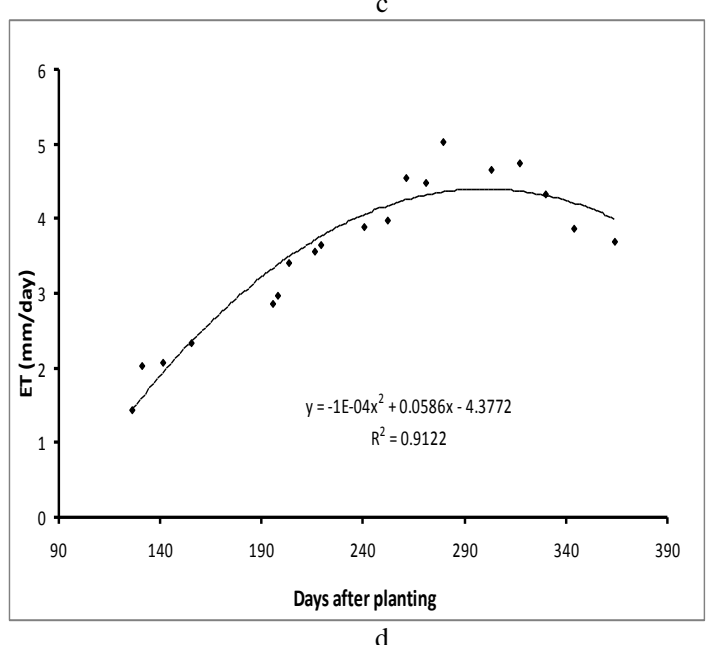

Fig. 1. Crop Evapotranspiration of musa on function of days after planting in treatments (a) T1 (b) T2 (c) T3 and (d) T0 during 2006/2007 experiment. 
There were variations in the crop evapotranspiration rates among treatments and this could be ascribed to the differential water application to treatments in which case the treatment that received high irrigation have sufficient water to meet evapotranspiration needs. This result compares well with the findings of Bassoi et al., [13] who reported a maximum of 7.3 mmday $^{-1}$ at the flowering stage during the first growing season, in a field experiment carried out to investigate the water consumption, crop coefficient and physiological behaviour of the banana crop in Brazil. Similar results have also been reported by [31]. The result also demonstrated that stress was evident in the rainfed treatment, T0 as established by the lower availability of water in the profile particularly in the dry periods of the year when compared to other treatments. Investigations by other researchers have shown that drought stress resulted in reduced plant growth [32]. It was also noticed that some plants in the control treatment permanently wilted before reaching maturity stage. This may not be unconnected with water stress at the sensitive stages of the crop (252-301DAP) which falls between the vegetative and flowering stages of the crops. Calvache [23] noted that flowering stage was the most sensitive to water stress in crops, particularly, for shallow rooted crops. Atteya [22] noted that water stress in plants induces a decrease in photosynthesis and growth. The rate of assimilation in the leaves is reduced as drought stress coinciding with flowering delays fruit bulking and results in an increase in the flowering initiation - fruit bulking interval and consequently a reduction in yield. This finding was also consistent with that of Antolin and Sanchez-Diaz [33], who reported reduced stem length of previously stressed compared with unstressed alfalfa. He concluded that drought inhibited cell elongation, reduced photosynthesis, interfered with nutrient uptake, and altered plant hormone levels.

The relationship observed between the measured consumptive use and biomass yield for each treatment are presented in Figure 2. Estimated water consumed ranged from $900 \mathrm{~mm}$ to $1700 \mathrm{~mm}$ from planting to harvest in the order of T0, T3, T2 and T1 treatments respectively. For example, in the fully irrigated treatment (T1), crop consumptive use at 413DAP (at harvest) was $1691.5 \mathrm{~mm}$ while crop consumptive use was $910.7 \mathrm{~mm}$ at same period for treatment $\mathrm{T} 0$. Correspondingly, highest biomass yield was 23.2 tha $^{-1}$ at harvest for T1 treatment while lowest value of biomass yield was 8.3 tha $^{-1}$ in T0 treatment. Statistical analysis confirmed that supplemental irrigation had significant effect $(\mathrm{p}<0.05)$ on biomass and bunch yield (Tables 4 and 5).

\subsection{Crop Water Productivity}

The computed crop water productivity in terms of water consumed $\left(\mathrm{CWP}_{\text {(water use) }}\right)$ and water applied $\left(\mathrm{CWP}_{\text {(water applied) }}\right)$ for the total plantain biomass are presented in Table 6 for $2006 / 2007$ and 2007/2008 experiments. CWP (water use) for the various treatments varied from $0.91-1.37 \mathrm{kgm}^{-3}$ for $2006 / 2007$ and $0.91-1.41 \mathrm{kgm}^{-3}$ in the $2007 / 2008$ seasons respectively while $\mathrm{CWP}_{\text {(water applied) }}$ varied from 2.82 $3.98 \mathrm{kgm}^{-3}$ and $2.89-4.04 \mathrm{kgm}^{-3}$ in the first and second seasons respectively. The $\mathrm{T} 1$ treatment which received a $581.7 \mathrm{~mm}$ depth of water in the first season cropping recorded the highest $\mathrm{CWP}_{\text {(water use) }}$ of $1.37 \mathrm{kgm}^{-3}$. The trend was the same in the second season. With the water application of $605.3 \mathrm{~mm}$, T1 recorded the highest $\mathrm{CWP}_{\text {(water }}$ use) of $1.41 \mathrm{kgm}^{-3} . \mathrm{T} 2$ treatment which received $467.2 \mathrm{~mm}$ depth of water in the first season recorded a CWP (water use) of
$1.21 \mathrm{kgm}^{-3}$ while in the second season with a water application of $517.2 \mathrm{~mm}, \mathrm{CWP}_{\text {(water use) }}$ was $1.24 \mathrm{kgm}^{-3}$. The least $\mathrm{CWP}_{\text {(water use) }}$ in the case of total biomass yield were recorded in treatment $\mathrm{T} 0$ (which received no water application) recorded a CWP (water use) values of 0.91 and 0.90 for 2006/2007 and 2007/2008 respectively.
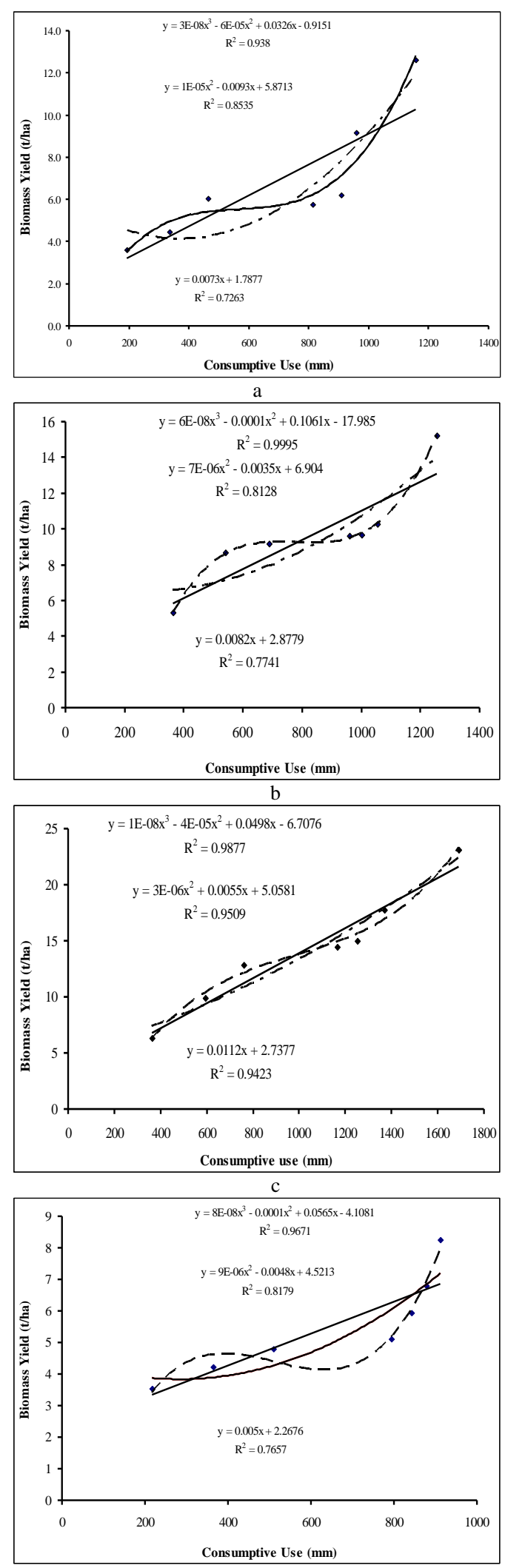

d

Fig. 2. Biomass Yield vs Seasonal Consumptive use for (a) T3 (b) T2 (c) $\mathrm{T} 1$ and (d) $\mathrm{T} 0$ 
Table 4. Total biomass yield, consumptive use, seasonal water applied and rainfall

\begin{tabular}{lllll}
\hline \multicolumn{5}{c}{$\mathbf{2 0 0 6 / 2 0 0 7}$ experiment } \\
\hline Treatment & Biomass yield & $\begin{array}{l}\text { Water } \\
\text { Applied } \\
(\mathrm{mm})\end{array}$ & $\begin{array}{l}\text { Rainfall } \\
(\mathrm{mm})\end{array}$ & $* \mathrm{CU}$ \\
& $(\mathrm{mm})$ \\
\hline T1 & $\left.23.22( \pm 2.2)^{*}\right)$ & 581.7 & 850 & 1691.5 \\
T2 & $15.24( \pm 0.7) \mathrm{b}$ & 467.2 & 850 & 1254.3 \\
T3 & $12.63( \pm 0.4) \mathrm{c}$ & 447.5 & 850 & 1157.1 \\
T0 & $8.25( \pm 2.1) \mathrm{d}$ & - & 850 & 910.7 \\
\hline \multicolumn{5}{c}{$\mathbf{2 0 0 7 / 2 0 0 8}$ Experiment } \\
\hline T1 & $24.44( \pm 1.8) \mathrm{a}$ & 605.3 & 927 & 1734.4 \\
T2 & $16.45( \pm 0.7) \mathrm{b}$ & 517.2 & 927 & 1328.6 \\
T3 & $14.16( \pm 1.1) \mathrm{c}$ & 489.6 & 927 & 1197.3 \\
T0 & $8.80( \pm 0.6) \mathrm{d}$ & - & 927 & 975.8 \\
\hline
\end{tabular}

*CU $=$ consumptive use. $* *$ Numbers in parenthesis show the standard deviations. Mean Values in the same column followed by different letters indicate significant differences according to Duncan's comparison of means at 5\% level

Table 5. Plantain bunch yield (dry), consumptive use, seasonal water applied and rainfall

\begin{tabular}{|c|c|c|c|c|}
\hline \multicolumn{5}{|c|}{ 2006/2007 experiment } \\
\hline Treatment & $\begin{array}{l}\text { Bunch yield } \\
\left(\text { tha }^{-1}\right)\end{array}$ & $\begin{array}{l}\text { Water } \\
\text { Applied } \\
(\mathrm{mm})\end{array}$ & $\begin{array}{l}\text { Rainfall } \\
(\mathrm{mm})\end{array}$ & $\begin{array}{l}{ }^{*} \mathrm{CU} \\
(\mathrm{mm})\end{array}$ \\
\hline $\mathrm{T} 1$ & $10.18( \pm 0.2)^{* * a}$ & 581.7 & 850 & 1691.5 \\
\hline $\mathrm{T} 2$ & $6.96( \pm 0.8) \mathrm{b}$ & 467.2 & 850 & 1254.3 \\
\hline T3 & $5.47( \pm 0.6) \mathrm{c}$ & 447.5 & 850 & 1157.1 \\
\hline T0 & $3.85( \pm 0.4) \mathrm{d}$ & - & 850 & 910.7 \\
\hline \multicolumn{5}{|c|}{ 2007/2008 Experiment } \\
\hline T1 & $12.89( \pm 2.3) \mathrm{a}$ & 605.3 & 927 & 1734.4 \\
\hline $\mathrm{T} 2$ & $7.52( \pm 0.7) b$ & 517.2 & 927 & 1328.6 \\
\hline T3 & $6.41( \pm 0.8) \mathrm{c}$ & 489.6 & 927 & 1197.3 \\
\hline T0 & $4.37( \pm 0.9) \mathrm{d}$ & - & 927 & 975.8 \\
\hline
\end{tabular}

*CU $=$ consumptive use. $* *$ Numbers in parenthesis show the standard deviations. Mean Values in the same column followed by different letters indicate significant differences according to Duncan's comparison of means at $5 \%$ level

Table 6. Crop water productivity for total biomass yield

\begin{tabular}{cccc}
\hline \multicolumn{4}{c}{$\mathbf{2 0 0 6 / 2 0 0 7}$} \\
\hline Treatment & $\begin{array}{c}\left(\mathrm{CWP}_{\text {(water use })}\right) \\
\mathrm{kgm}^{-3}\end{array}$ & $\begin{array}{c}\left(\mathrm{CWP}_{\text {(water applied) }}\right) \\
\mathrm{kgm}^{-3}\end{array}$ & $\begin{array}{c}\mathrm{CWP}_{\text {(economic) }} \\
\mathbf{\$ m}^{-3}\end{array}$ \\
\hline T1 & 1.37 & 3.98 & 5.29 \\
$\mathrm{~T} 2$ & 1.21 & 3.26 & 4.33 \\
$\mathrm{~T} 3$ & 1.09 & 2.82 & 3.75 \\
$\mathrm{~T} 0$ & 0.91 & - & - \\
\hline \multicolumn{4}{c}{$\mathbf{2 0 0 7 / 2 0 0 8}$} \\
T1 & 1.41 & 4.04 & 5.37 \\
T2 & 1.24 & 3.18 & 4.23 \\
T3 & 1.18 & 2.89 & 3.84 \\
T0 & 0.90 & - & - \\
\hline
\end{tabular}

Table 7 shows the $\mathrm{CWP}_{\text {(water use), }} \mathrm{CWP}_{\text {(water applied) }}$ and $\mathrm{CWP}_{\text {(economic) }}$ in the case of plantain bunch yield for 2006/2007 and 2007/2008 seasons respectively. CWP (water use) for the various treatments varied from $0.42-0.60 \mathrm{kgm}^{-3}$ and $0.45-0.74 \mathrm{kgm}^{-3}$ for the first and second seasons respectively. T1 which received $581.7 \mathrm{~mm}$ depth of water in the season had the highest $\mathrm{CWP}_{\text {(water use) }}$ of $0.60 \mathrm{kgm}^{-3}$. The trend was the same in 2007/2008 season. With water application depth of $605.3 \mathrm{~mm}$, the $\mathrm{CWP}_{\text {(water use) }}$ value was $0.74 \mathrm{~kg}^{-3}$. T2 treatment received $467.2 \mathrm{~mm}$ depth of water had CWP (water use) value of $0.55 \mathrm{kgm}^{-3}$ in first season cropping. The value was $0.57 \mathrm{kgm}^{-3}$ for a water application depth of $517.2 \mathrm{~mm}$ for $2007 / 2008$. T0 had the least values of $\mathrm{CWP}_{\text {(water use) }}$ amongst the various treatments with values of 0.42 and $0.45 \mathrm{kgm}^{-3}$ respectively. T0 depended on climate throughout the growing season except water received for establishment. These results implied that T1 produced 60 and $74 \mathrm{kgha}^{-1}$ of bunch yields for the first and second seasons when compared to 55,47 and $42 \mathrm{kgha}^{-1}$ produced by T2, T3 and T0 respectively for the first season and 57, 54 and $45 \mathrm{kgha}^{-1}$ produced for $\mathrm{T} 2, \mathrm{~T} 3$ and $\mathrm{T} 0$ respectively for the second season.

Table 7. Crop water productivity for bunch yield

\begin{tabular}{cccc}
\hline \multicolumn{4}{c}{$\mathbf{2 0 0 6 / 2 0 0 7}$} \\
\hline Treatment & $\begin{array}{c}\left(\mathrm{CWP}_{\text {(water use) }}\right) \\
\mathrm{kgm}^{-3}\end{array}$ & $\begin{array}{c}\left(\mathrm{CWP}_{\text {(water applied) }}\right) \\
\mathrm{kgm}^{-3}\end{array}$ & $\begin{array}{c}\mathrm{CWP}_{\text {(economic) }} \\
\$ \mathrm{~m}^{-3}\end{array}$ \\
\hline T1 & 0.60 & 1.76 & 2.33 \\
$\mathrm{~T} 2$ & 0.55 & 1.49 & 1.98 \\
$\mathrm{~T} 3$ & 0.47 & 1.22 & 1.63 \\
$\mathrm{~T} 0$ & 0.42 & - & - \\
\hline \multicolumn{5}{c}{$\mathbf{2 0 0 7 / 2 0 0 8}$} \\
T1 & 0.74 & 2.13 & 2.83 \\
T2 & 0.57 & 1.45 & 1.93 \\
T3 & 0.54 & 1.31 & 1.74 \\
T0 & 0.45 & - & - \\
\hline
\end{tabular}

A comparison of $\mathrm{CWP}_{\text {(water use) }}$ for all treatments showed that bunch production per unit of water used for T1 was about 8, 22 and $30 \%$ higher than treatments T2, T3 and T0 respectively in the first season. In the second season, plantain bunch produced per unit of water used in T1 was about 23, 27 and 39\% respectively. The implication of this was that treatment $\mathrm{T} 1$ had a better water utilization efficiency than treatments T2, T3 and T0 in both seasons. Better water utilization efficiency in $\mathrm{T} 1$ may be associated with adequate water applied during the growth stages.

Crop water productivity expressed in terms of water applied $\left(\mathrm{CWP}_{\text {(water applied) }}\right)$ varied from $1.22-1.76$ and $1.31-$ 2.13 for seasons one and two respectively. In T1, the highest values of $\mathrm{CWP}_{\text {(water applied) }}$ were recorded for both seasons. With seasonal water depths of 581.7 and $605.3 \mathrm{~mm}$, the $\mathrm{CWP}_{\text {(water applied) }}$ were 1.76 and $2.13 \mathrm{kgm}^{-3}$ for seasons one and two respectively. The lowest $\mathrm{CWP}_{\text {(water applied) }}$ were recorded in the T3 which received seasonal water depths of 447.5 and $489.6 \mathrm{~mm}$ in seasons one and two respectively.

$\mathrm{CWP}_{\text {(water applied) }}$ is an indicator of how much the total water applied in the field was efficiently harnessed for production benefit. This means that in $\mathrm{T} 1,176$ and $213 \mathrm{kgha}^{-1}$ of plantain bunch was produced from every $100 \mathrm{~m}^{3}$ applied to grow the crop in the first and second seasons respectively. T2 produced 149 and $145 \mathrm{kgha}^{-1}$ bunch for every $100 \mathrm{~m}^{3}$ of water applied in first and second seasons, while T3 produced 122 and $131 \mathrm{kgha}^{-1}$ for every $100 \mathrm{~m}^{3}$ of water applied also in the first and second seasons respectively. The economic crop water productivity varied from $1.63 \$ / \mathrm{m}^{3}$ and $1.74 \$ / \mathrm{m}^{3}$ in the treatment which received the lowest seasonal water applied to grow the crop to highest values of $2.33 \$ / \mathrm{m}^{3}$ and $2.83 \$ / \mathrm{m}^{3}$ in T1 for seasons 2006/2007 and 2007/2008 respectively. The economic crop water productivity has similar trend with $\mathrm{CWP}_{\text {(water applied). }}$.

The ranges of crop water productivity from the treatment were closer to the range of 1.2 and $3.7 \mathrm{kgm}^{-3}$ reported in 
literature for banana crop around the world. Hedge and Srivas [10] estimated water use efficiency (WUE) of banana cv. Robusta ranging from $2.8-3.7 \mathrm{kgm}^{-3}$ according to the soil water availability. Bassoi et al., [13] reported $1.17 \mathrm{kgm}^{-3}$ for banana cv. Pacovan. The CWP reported here far exceeded the crop water productivity reported for maize which varied from $0.3-2.7 \mathrm{kgm}^{-3}[30,34,35]$. It must however be noted that crop water productivity values are influenced by crop variety and water management practices. Van Dam and Malik, [36] and Hartfield et al., [37] observed that water use efficiency is influenced by crop morphology, soil conditions, agricultural practices and atmospheric variables.

\section{Conclusion}

Crop water consumed varied significantly $(\mathrm{P}<0.05)$ among treatments. Estimated water consumed ranged from $900 \mathrm{~mm}$ to $1700 \mathrm{~mm}$ from planting to harvest depending on the irrigation water regime. This confirms that plantain respond favourably to water. Supplemental irrigation had significant effect $(p<0.05)$ on biomass yield. The biomass yield in the highly irrigated treatment was about $280 \%$ that of control treatment.

Crop Water Productivity (CWP) in terms of water consumed (i.e. Water use efficiency, (WUE) varied from 91 to $137 \mathrm{kgha}^{-1}$ of biomass per $100 \mathrm{~m}^{3}$ of water consumed according to level of irrigation water regime. Hence plantain has a better utilization of water consumed when irrigated. Similarly CWP in terms of water applied varied from 398 to $282 \mathrm{kgha}^{-1}$ of biomass per $100 \mathrm{~m}^{3}$ of water consumed according to level of irrigated water regime.
CWP in terms of water consumed (i.e. Water use efficiency, (WUE) varied from 42 to $60 \mathrm{kgha}^{-1}$ of bunch yield per $100 \mathrm{~m}^{3}$ of water consumed according to the level of irrigation water applied. Similarly CWP in terms of water applied varied from 122 to $176 \mathrm{kgha}^{-1}$ of bunch yield per $100 \mathrm{~m}^{3}$ of water consumed according to the level of irrigation water applied. The status of crop water productivity (either maximized or reduced), was dictated by the amount of water applied and the crop growth stages. Generally highly irrigated treatment showed higher CWP than other lower irrigation treatments and control which showed that plantain respond favourably to water application. In the rainfed farming systems of the tropical region, where water supply is often limited due to erratic rainfall pattern, agronomic practices should aim to utilize the water available for crop growth in an efficient way. Improved production from a limited water supply can result from increasing the total amount of water used by the crop through supplemental irrigation. Therefore, to achieve higher CWP and profitability from this crop, supplemental irrigation was required to grow the crop in rainfed tropical regions.

\section{Acknowledgements}

Authors' acknowledge the assistance of the management of Rufus Giwa Polytechnic, Owo, Nigeria and the Federal University of Technology, Akure, Nigeria for the research assistance provided and the use of the university research farm and facilities for the research work.

\section{References}

1. D. Hallam, 1995. The world banana economy. In: Bananas and Plantains. Champman and Hall, London U.K. 509-533.

2. FAO., 1999. http://www.fao.org

3. R. H. Stover, N. W. Simmonds, 1987. Bananas. 3rd. Edition, Longman, London. 468pp.

4. P. R. Rowe, 1998. A banana breeder's response to 'The global program for Musa improvement' INFOMUSA 7(1): PROMUSA.

5. J. C. Obiefuna, 1986. The effects of monthly planting on yield, yield patterns and yield decline of plantains (Musa AAB). Scientia Horticulturae 29: 47 - 54

6. K. P. Baiyeri, B. N. Mbah, (1994). Growth and yield correlation in Falsehorn plantain (Musa AAB cv. Agbagba) in a sub-humid zone of Nigeria. MusAfrica 5: $3-4$

7. K. P. Baiyeri, A. R. Ajayi, 2000. Status and constraints of Musa spp. production in a sub-humid zone of Nigeria. Acta Horticulturae 540: $73-77$

8. A. Rodríguez Saavedra, J. L. Rodríguez Martínez, 1999. Socioeconomic aspects of plantain cultivation in Colombia. INFOMUSA 10: 4-9

9. S. N. Asoegwu, J. C. Obiefuna, 1987. Effect of irrigation on late season plantains. Tropical Agriculture 64(2):139-143.

10. D. M. Hedge, K. Srinivas, 1989. Irrigation and nitrogen fertility influences on plant water relation, biomass, and nutrient accumulation and distribution in banana cv. Robusta. J. Hort. Sci. 64(1): 91-98.

11. J. C. Robinson, A. J. Alberts, 1989. Seasonal variations in the crop water-use coefficient of banana (cultivar 'Williams') in the Subtropics. Sci. Hortic. $40: 215-225$

12. R. Goenaga, H. Irizarry, E. Gonzalez, 1989. Water requirement of plantains (musaaccuminata x Musa balbisians AAB grown under semi-arid conditions. Tropical Agriculture 70, 3-7.

13. L. H. Bassoi, A. H. Teixeira, J. M. P. Eilho, J. A. M. Silva, E. E. G. Silva, C. M. C. Ramos, and G. C. Sediyama, 2004. Guidelines for Irrigation Scheduling of Banana Crop in Sảo Fransisco valley, Brazil. II - Water consumption, Crop Coefficient and Physiolgical Behaviour. Rev. Bras. Frutic, Jaboticabal - SP. v. 26 No. 3 pp464467. December 2004.

14. J.Champion, 1968. El plátano. Bacelona Blume. 247p

15. J. C. Robinson, 1995. Bananas and Plantains. CAB International, UK. pp 238

16. N. C. Turner, A. B. Hearn, J. E. Begg, G. A. Constable, 1986 Cotton (Gossypium hirsutum L.): Physilogical and morphological responses to water deficits and their relationship to yield. Field Crops Res. 14:153-170.

17. R. A. Ball, D. M. Oosterhuis, A. Mauromoustakos, 1994. Growth dynamics of the cotton plant during water deficit stress. Agron. J. 86:788-795.

18. T. J. Gerik, K. L. Faver, P. M. Thaxton, K. M. El-Zik, 1996. Late season water stress in cotton. 1. Plant growth, water use, and yield. Crop Sci. 36:914-921.

19. B. L. McMichael, 1982. Field investigations of the response of cotton to water deficits. Field Crops Res. 5:319-333.

20. J. E. Ephrath, A. Marani, B. A. Bravdo, 1990. Effects of moisture stress on stomatal resistance and photosynthetic rate in cotton (Gossypium hirsutum) 1. Controlled levels of stress . Field Crops Res. 23:117-131.

21. K. L. Faver, T. J. Gerik, P. M. Thaxton, K. M. El-Zik, 1996. Late season water stress in cotton: 11. Leaf gas exchange and assimilation capacity. Crop Sci. 36:922-928.

22. A. M. Atteya, 2003. Alteration of water relations and yield of corn genotypes in response to drought. Bulg. J. Plant Physiol. (2961-2): 63-76.

23. M. Calvache, and K. Reichardt, 1997. Effects of water stress imposed at different plant growth stages of common bean (pahaseolus vulgaris) on yield and Nitrogen fixation. In: C. Kirda, Mountonnet, C. P. Hera, and D. R. Nielson, (eds.). Crop yield 
response to deficit irrigation. Dordrecht, The Netherlands. Kluwer Academic Publishers.

24. J. C. Robinson, J. P. Bower, 1987. Transpiration characteristics of banana leaves (cultivar "Williams") in response to progressive depletion of available soil moisture. Sci. Hortic. Amsterdam, 30: 289-300.

25. K. Eckstein, J. C. Robinson, S. J. Davie, 1995. Physiological responses of banana (Musa AAA, Cavendish subgroup) in the subtropics. III. Gas exchange, growth analysis and source-sink interaction over a complete crop cycle. Journal of Horticultural Science 70: 169-180.

26. K. Eckstein, J. C. Robinson, 1996. Physiological responses of Banana (Musa AAA:Cavendish Subgroup) in the Subtropics VI: Seasonal Responses of leaf gas exchange to Short term water stress. Journal of Horticultural Science. 71: 145-155.

27. P. V. Azevedo, B. B. da Silva, V. P. R. da Silva, 2003. Water requirements of irrigated mango orchards in Northeast Brazil. Agric. Water Management 58 (3), 241-254.

28. R. Goenaga andH.Irizarry, (1995). Yield performance of banana irrigated with fractions of Class A pan evaporation in a semiarid environment. Agronomy Journal 87: 172-176.

29. R. G. Allen, L. S. Pereira, D. Raes, M. Smith, (1998). Crop evapotranspiration: Guidelines for computing crop requirements. Irrigation and Drainage Paper No. 56, FAO, Rome, Italy, 300pp.

30. X. Zhang, 2002. Linking water balance to irrigation scheduling: a case study in the Piedmont of Mount Taihang. In: McVicar, T.R., Rui, L., Walker, J., Fitzpatrick, R.W., Changming, L. (Eds.),
Regional Water and Soil Assessment for Managing Sustainable Agriculture in China and Australia. ACIAR Monograph no. 84 pp57-69.

31. R. Goenaga, H. Irizarry, Irrigated banana yield and quality of banana irrigated with fractions of class a pan evaporation on an oxisol Agron. J., 92 (2000), pp. 1008-1012

32. P. W. Brown, and C. B. Tanner. 1983. Alfalfa stem and leaf growth during water sress. Agron. J.,75: 799-805.

33. M.C. Antolin, M. Sanchez-Diaz, 1993. Effects of temporary droughts on photosynthesis of alfalfa plants. J. Exp. Bot. 44, 13411349.

34. W.G. Bastiaanssen, J. C.Van Dam, and P. Droogers, 2003. Introduction. In: J. C. Van Dam, R.S. Malik, (Eds.), water productivity of irrigated crops in Sirsa District India. Integration of remote sensing, crop and soil models and geographical information systems. pp11-20.

35. H. E.Igbadun, H. F. Mahoa, K. P. R. Andrew, A. B. Tarimo Salim, 2006. Crop water productivity of an irrigated maize crop in Mkoji sub-catchment of the Great Ruaha River Basin, Tanzania. Agricultural Water Management, 85: 141-150.

36. J.C. Van Dam, R.S. Malik, 2003. Water productivity of irrigated crops in Sirsa District, India. Integration of Remote Sensing, Crop and Soil Models and Geographical Information Systems. WATPRO Final Report. CABI Publications, UK, p. 163.

37. J. L. Hartfield, T. J. Sauer, J. H. Prueger, 2001. Managing soils to achieve greater water use efficiency: a review. Agronomy J. 93(2), 271-280. 